\title{
29. SULFUR ISOTOPE RATIOS OF LEG 126 IGNEOUS ROCKS ${ }^{1}$
}

\author{
Peter Torssander ${ }^{2}$
}

\begin{abstract}
Sulfur isotope ratios have been determined in 19 selected igneous rocks from Leg 126 . The $\delta^{34} \mathrm{~S}$ of the analyzed rocks ranges from $-0.1 \%$ to $+19.60 \%$. The overall variation in sulfur isotope composition of the rocks is caused by varying degrees of seawater alteration. Most of the samples are altered by seawater and only five of them are considered to have maintained their magmatic sulfur isotope composition. These samples are all from the backarc sites and have $\delta^{34} \mathrm{~S}$ values varying from $+0.2 \%$ o to $+1.6 \%$ o of which the high $\delta^{34} \mathrm{~S}$ values suggest that the earliest magmas in the rift are more arc-like in their sulfur isotope composition than the later magmas. The $\delta^{34} \mathrm{~S}$ values from the forearc sites are similar to or heavier than the sulfur isotope composition of the present arc.
\end{abstract}

\section{INTRODUCTION}

Sulfur is a volatile element that can be degassed during the ascent of basaltic magma. Degassing causes sulfur isotope fractionation; the isotopic composition of sulfur in rocks can vary with the concentration. The sulfur isotope composition of the rock is, however, also dependent on its source and formation. Sulfur concentration is relatively high in mid-ocean ridge basalt (MORB) and ocean island basalt (OIB) (Kanehira et al., 1973; Sakai et al., 1982, 1984; Torssander, 1989 ) and generally comparable to Moore and Fabbi's (1971) estimate of $800 \pm 150 \mathrm{ppm}$ for undegassed basalts. Compared with these levels, Garcia et al. (1979) found a sulfur content in rocks from the Mariana Arc of only $60 \mathrm{ppm}$, whereas the sulfur content in the Mariana Trough basalt glasses reported by Kusakabe et al. (1990) is $620 \mathrm{ppm}$. Furthermore, Japanese volcanic arc rocks also contain a sulfur concentration that is much less than that of MORB, typically less than $40 \mathrm{ppm}$; Ueda and Sakai (1984) suggested that the primary magmas forming island arc volcanic rocks are intrinsically depleted in sulfur $(\leq 120 \mathrm{ppm})$. Sumisu Rift basalts collected from the Alvin dive range in sulfur concentration from 129 to $253 \mathrm{ppm}$ (Hochstaedter et al., 1990).

There is a marked consistency between $\delta^{34} \mathrm{~S}$ data from MORB and OIB: the average $\delta^{34} \mathrm{~S}\left(-0.6 \%\right.$ to $-0.8 \%$ ) and the range in $\delta^{34} \mathrm{~S}$ (from $-2.0 \%$ o to $+0.5 \%$ o ) are similar in the degassed basalts of Kilauea (Sakai et al., 1982), Iceland (Torssander, 1989), and the $\delta^{34} \mathrm{~S}$ of sulfide sulfur from MORBs (Puchelt and Hubberten, 1980; Grinenko et al., 1975; Sakai et al., 1984). However, the average $\delta^{34} \mathrm{~S}$ of total sulfur in submarine basalts varies from $+0.3 \%$ o to $+0.7 \%$ o. The good agreement between all these closely related studies and with continental tholeiites (with $\delta^{34} \mathrm{~S}=-0.03 \%$ oo, Harmon et al., 1987; between $0 \%$ and $+1.0 \%$, Smitheringale and Jensen, 1963; Shima et al., 1963) suggests that the depleted mantle is homogeneous in its sulfur isotope composition. However, ion microprobe measurements of sulfide inclusions in diamonds have a large range in $\delta^{34} \mathrm{~S}$, which suggests that the mantle is heterogeneous in its sulfur isotope composition (Chaussidon et al., 1987). In comparison to $\delta^{34} \mathrm{~S}$ values from arc and backarc environments, fresh glasses from Mariana Trough basalts have $\delta^{34} \mathrm{~S}$ values of about $-0.6 \%$ \% (Kusakabe et al., 1990), whereas the $\delta^{34} \mathrm{~S}$ values in Mariana Arc vary from $+2 \%$ to $+20 \%$ (Woodhead et al., 1987). Japanese volcanic rocks have also high $\delta^{34} \mathrm{~S}$ values,

\footnotetext{
${ }^{1}$ Taylor, B., Fujioka, K., et al., 1992. Proc. ODP, Sci. Results, 126: College Station, TX (Ocean Drilling Program).

2 Department of Geology and Geochemistry, Stockholm University, S-106 91 Stockholm, Sweden.
}

from $0 \%$ to $+9 \%$ (Ueda and Sakai, 1984), which could arise from inhomogeneities in the mantle but are more likely a result of contamination from the subducting slab (A. Ueda, pers. comm., 1988).

Leg 126 of the Ocean Drilling Program (ODP) drilled seven sites in the backarc and forearc of the Izu-Bonin Arc (Fig. 1). At the backarc sites in the Sumisu Rift, the geological processes associated with renewed rifting before backarc spreading were investigated, whereas drilling at the forearc sites revealed that the forearc basin also was formed by rifting. The basement of backarc Sites 790 and 791 consists largely of basaltic rocks, whereas the igneous rocks recovered from forearc Sites 792 and 793 are andesites.

The purpose of this study is to determine the $\delta^{34} S$ of selected igneous rocks in a transect across backarc and forearc basins and whether they bear in their $\delta^{34} \mathrm{~S}$ values any of the igneous characteristics from the mantle source beneath the system.

\section{METHODS}

The samples were typically $10-\mathrm{cm}^{3}$ minicores or $30-\mathrm{cm}^{3}$ splits from the cored rocks. They were ultrasonically washed in distilled water before crushing. This treatment was used to avoid the dissolution of acid-soluble sulfides from the rocks, because it is a much less aggressive treatment than that applied for the Sumisu Rift basalts, in which the rocks were heated at $60^{\circ} \mathrm{C}$ for $1 \mathrm{hr}$ in $3 \mathrm{~N} \mathrm{HCl}$ acid (Hochstaedter et al., 1990). Between 5 and $10 \mathrm{~g}$ of the finely powdered rock samples was reacted in each analysis. The extraction of sulfur was made with stannous ion in dehydrated phosphoric acid ("Kiba reagent") at $280^{\circ} \mathrm{C}$ under vacuum (Kiba et al., 1955; Ueda and Sakai, 1983). Sulfate and sulfide sulfur in the rocks are liberated as $\mathrm{SO}_{2}$ and $\mathrm{H}_{2} \mathrm{~S}$, respectively. During the reaction about $10 \%$ of the sulfate sulfur in the rock reduced to $\mathrm{H}_{2} \mathrm{~S}$ with a fractionation of $11 \%$. All the sulfur analytical and isotopic determinations are corrected for this $10 \%$ reduction. Water and $\mathrm{CO}_{2}$ are also liberated during the reaction. All these gases were separated from each other by successive vacuum distillation, using pentane traps and ethanol-dry ice baths and liquid nitrogen. The $\mathrm{H}_{2} \mathrm{~S}$ was converted to $\mathrm{SO}_{2}$ by reaction with $\mathrm{Cu}_{2} \mathrm{O}$ at a temperature of $900^{\circ} \mathrm{C}$ (Robinson and Kusakabe, 1975). The two forms of $\mathrm{SO}_{2}$ were analyzed separately isotopically and volumetrically. The isotope ratio of $\mathrm{SO}_{2}$ was measured with a modified Micromass 602 mass spectrometer at the Naturhistoriska Riksmuseet in Stockholm.

The blank test of the "Kiba reagent" did not reveal any measurable amount of sulfur dissolved from the glass of the reaction vessel. The sulfur isotope composition is given in the conventional $\delta$ notation relative to Cañon Diablo Troilite. The accuracy is generally better than $\pm 0.2 \%$ o, and for most of the samples it is better than $\pm 0.5 \%$ because of the low sulfur contents. The uncertainty of the chemical analysis of sulfur by these procedures is $\pm 5 \%$. 


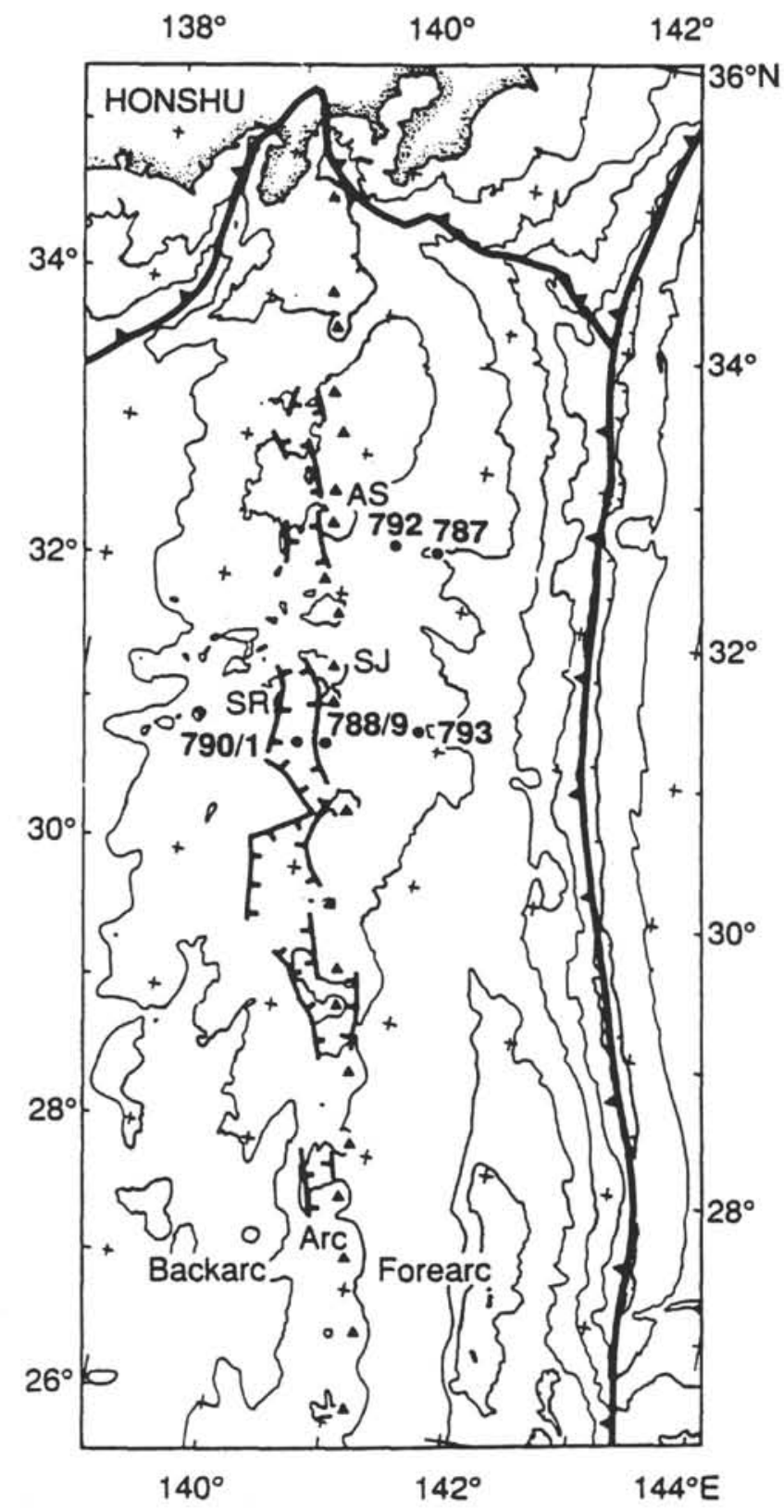

Figure 1. Location of sites drilled during Leg 126. AS = Aoga Shima, SJ = Sumisu Jima, and SR = Sumisu Rift.

\section{RESULTS}

The sulfur content and isotopic composition of the rocks are given in Table 1. The sulfur content of all the samples varies between 1 and $153 \mathrm{ppm}$ and the distribution of $\delta^{34} \mathrm{~S}$ is from $-0.1 \%$ oo to $+19.6 \%$ (Table 1 ).

\section{Backarc Sites 790 and 791}

At Sites 790 and 791 highly vesicular sparsely phyric basalts underlie sediments 1.1 m.y. old. Gill et al. (this volume) divided the basement into four categories: (1) basement of Site 790 and the top of Site 791 (igneous stratigraphic Units 2, 3, 5, 6, 7, and 10); (2) main breccia unit of Site 791 (called mousse by the shipboard petrologists because of its frothy appearance and described in detail by Gill et al. [1990]); (3) dikes that intrude the basement of Site 791 (Units 4, 8, 15 , and 17); and (4) pervasively altered material beneath the mousse.

\section{Basement Lavas}

The lavas have a modal phenocryst assemblage consisting of $3 \%$ or less olivine, between $5 \%$ and $20 \%$ plagioclase, and much less than $1 \%$ spinel. The differentiation is tholeiitic in character, showing Fe-Ti enrichment. Overall, the difference between the lavas is the same as the one found among the samples of Sumisu Rift basalts (Gill et al., this volume; Hochstaedter et al., 1990). The trace element compositions and isotope ratios of $\mathrm{Sr}$ and $\mathrm{Nd}$ are also similar to those of the Sumisu Rift basalts. The sulfur isotope results from Site $790\left(\delta^{34} \mathrm{~S}\right.$ from $+0.2 \%$ oo to $+1.0 \%$ oo are also comparable to those of the Sumisu Rift basalts $\left(\delta^{34} \mathrm{~S}\right.$ from $-2.3 \%$ to $+0.5 \%$ o $)$. Bulk sulfur concentrations are, however, much lower, at about $5 \mathrm{ppm}$.

The sulfur isotope ratios from the top of Site 791 are strikingly heavy, ranging from $+9 \%$ to $+11 \%$, with similar $\delta^{34} S$ values for both sulfide and sulfate sulfur and a sulfur concentration between 6 and $153 \mathrm{ppm}$.

\section{Basaltic Breccia Mousse (Units 11, 12, and 14)}

This 135-m-thick clastic basalt forms almost half of the basement at Site 791. Both the clasts and the glassy matrix are honeycombed with small vesicles, totaling $30 \%-50 \%$ porosity. The mousse consists of three highly vesicular components: (1) juvenile glass clasts, (2) a fine-grained, glass-rich juvenile matrix, and (3) lithic clasts (Gill et al., this volume). Both the glass clasts and the fine-grained matrix are considered to have formed during deep-water explosive eruption, whereas the lithic clasts are thought to be accidental. The mousse is interpreted to consist of one juvenile component, as the fine-grained matrix consists of thoroughly disrupted glass clasts. The difference between the glass clasts and the fine-grained matrix is discussed in Gill et al. (this volume).

In this chapter, the glass clasts and the fine-grained matrix are treated as one component (matrix) unless otherwise stated. The lithic clast glass is tachylite and not as fresh as the sideromelane glass in the matrix. The matrix has a chemistry similar to that of the overlying lavas whereas the lithic clasts are somewhat more like arc tholeiites than MORB (Gill et al., this volume). Sulfur concentrations and isotopic compositions differ between the clasts and matrix. The matrix is almost barren of sulfate with a sulfur concentration of $29 \mathrm{ppm}$ and a $\delta^{34} \mathrm{~S}$ value between $+0.7 \%$ and $+1.6 \%$. The lithic clasts have a high sulfate sulfur concentration $(40-90 \mathrm{ppm})$ and a low sulfide sulfur concentration of $6 \mathrm{ppm}$ or less. The $\delta^{34} \mathrm{~S}$ of sulfate sulfur and total sulfur varies from $+11.0 \%$ o to $+19.6 \%$, but one sample of sulfide sulfur is $+10.9 \%$ o.

\section{Dikes}

Some of the dikes span the same range in differentiation as the lavas whereas others are the most differentiated material recovered at the sites (Gill et al., this volume). However, the sulfur concentration in the dike samples is $\leq 2 \mathrm{ppm}$ and the sulfur isotope composition could not be determined.

\section{Forearc Sites 792 and 793}

Igneous rocks (andesites) were encountered beneath lower Oligocene sediments at both sites. At Site 793, a mid-Miocene diabase sill with a thickness of approximately $4.5 \mathrm{~m}$ was encountered.

\section{Site 792}

Basement at Site 792 consists of highly porphyritic two-pyroxene andesites interbedded with thin layers of hyaloclastic and volcaniclastic material. The andesites are interpreted to be a sequence of massive lava flows. The phenocrysts are dominated by plagioclase by as much as $25 \%-35 \%$, whereas pyroxene (both orthopyroxene and clinopy- 
Table 1. Sulfur concentration and isotopic composition of Leg 126 igneous rocks.

\begin{tabular}{|c|c|c|c|c|c|c|c|}
\hline $\begin{array}{l}\text { Core, section, } \\
\text { interval }(\mathrm{cm})\end{array}$ & Rock type & $\begin{array}{l}\text { Sulfide } \\
\text { S } \\
\text { (ppm) }\end{array}$ & $\begin{array}{l}\text { Sulfate } \\
\text { S } \\
\text { (ppm) }\end{array}$ & $\underset{(\mathrm{ppm})}{\Sigma S}$ & $\begin{array}{l}\text { Sulfide } \\
\delta^{34} \mathrm{~S} \\
(\% \circ)\end{array}$ & $\begin{array}{l}\text { Sulfate } \\
\delta^{34} S \\
(\%)\end{array}$ & $\begin{array}{c}\delta^{34} S \\
\Sigma S \\
(\%)\end{array}$ \\
\hline $\begin{array}{l}\text { 126-790C- } \\
21 \mathrm{X}-\mathrm{CC}, 10-22 \\
24 \mathrm{X}-\mathrm{CC}, 10-12 \\
33 \mathrm{X}-\mathrm{CC}, 2-3\end{array}$ & $\begin{array}{l}\text { Basalt } \\
\text { Basalt } \\
\text { Basalt }\end{array}$ & $\begin{array}{l}5 \\
1 \\
4\end{array}$ & $\begin{array}{l}1 \\
2 \\
3\end{array}$ & $\begin{array}{l}6 \\
3 \\
7\end{array}$ & $\begin{array}{l}+0.2 \\
-\end{array}$ & $\bar{z}$ & $\begin{array}{l}+0.2 \\
+1.0 \\
+0.7\end{array}$ \\
\hline $\begin{array}{l}\text { 126-791B- } \\
\text { 50R-1,8-13 } \\
\text { 53R-1,6-8 } \\
\text { 56R-1,46-50 } \\
\text { 60R-1,5-9 } \\
61 \mathrm{R}-1,8-11 \\
62 \mathrm{R}-1,29-31 \\
62 \mathrm{R}-151-53 \\
62 \mathrm{R}-1,88-92 \\
\text { 67R-1,61-63 }\end{array}$ & $\begin{array}{l}\text { Basalt } \\
\text { Basalt } \\
\text { Diabase } \\
\text { Basalt } \\
\text { Diabase } \\
\text { Basalt mousse clast } \\
\text { Basalt mousse matrix } \\
\text { Basalt mousse clast } \\
\text { Basalt mousse matrix }\end{array}$ & $\begin{array}{r}123 \\
86 \\
2 \\
5 \\
1 \\
6 \\
29 \\
0 \\
28\end{array}$ & $\begin{array}{r}30 \\
40 \\
0 \\
1 \\
0 \\
88 \\
1 \\
1 \\
38 \\
1\end{array}$ & $\begin{array}{r}153 \\
126 \\
2 \\
6 \\
1 \\
94 \\
30 \\
38 \\
29\end{array}$ & $\begin{array}{r}+9.7 \\
+9.5 \\
+\overline{9} .2 \\
-\overline{0} \\
+10.9 \\
+1.6 \\
\overline{+0} .7\end{array}$ & $\begin{array}{c}+10.9 \\
+11.0 \\
- \\
- \\
+\overline{11} .0 \\
+\overline{19} .6 \\
-\end{array}$ & $\begin{array}{r}+10.0 \\
+10.1 \\
- \\
+\overline{+9} .2 \\
+11.0 \\
+1.6 \\
+19.6 \\
+0.7\end{array}$ \\
\hline $\begin{array}{l}\text { 126-792E- } \\
72 \mathrm{R}-1,111-115 \\
75 \mathrm{R}-1,50-55 \\
78 \mathrm{R}-1,131-136\end{array}$ & $\begin{array}{l}\text { Andesite } \\
\text { Andesite } \\
\text { Andesite }\end{array}$ & $\begin{array}{r}20 \\
7 \\
3\end{array}$ & $\begin{array}{l}0 \\
1 \\
4\end{array}$ & $\begin{array}{r}20 \\
8 \\
7\end{array}$ & $\begin{array}{l}+5.3 \\
+4.6 \\
-\end{array}$ & $\begin{array}{l}- \\
-\end{array}$ & $\begin{array}{r}+5.3 \\
+4.6 \\
+12.9\end{array}$ \\
\hline $\begin{array}{l}\text { 126-793A- } \\
\text { IR-1, 27-32 }\end{array}$ & Diabase sill & 6 & 1 & 7 & -0.1 & - & -0.1 \\
\hline $\begin{array}{l}\text { 126-793B- } \\
93 \mathrm{R}-1,100-104 \\
99 \mathrm{R}-1,116-121 \\
105 \mathrm{R}-3,93-98\end{array}$ & $\begin{array}{l}\text { Andesite } \\
\text { Andesite } \\
\text { Andesite }\end{array}$ & $\begin{array}{l}4 \\
5 \\
4\end{array}$ & $\begin{array}{l}2 \\
3 \\
2\end{array}$ & $\begin{array}{l}6 \\
8 \\
6\end{array}$ & $\begin{array}{l}+3.0 \\
+8.9 \\
+3.0\end{array}$ & $\overline{-}$ & $\begin{array}{l}+3.0 \\
+8.9 \\
+3.0\end{array}$ \\
\hline
\end{tabular}

roxene) is less than $15 \%$. The interstitial glass is always altered and not preserved. Geochemically they are calc-alkaline andesites, but they are less enriched in low-field-strength elements than most arc lavas. The sulfur isotope distribution varies between $+4.6 \%$ and $+12.9 \%$ and the sulfur concentration in the rocks is between 7 and $20 \mathrm{ppm}$.

\section{Site 793}

At Site 793 igneous rocks were encountered both at shallow depths ( $600 \mathrm{~m}$ below seafloor [mbsf]) as an olivine diabase sill and forming basement at $1400 \mathrm{mbsf}$. Olivine phenocrysts and interstitial glass are always altered to smectite in the olivine diabase sill but the other minerals are fresh. The sulfur concentration is $7 \mathrm{ppm}$ sulfur and the $\delta^{34} \mathrm{~S}$ value is $-0.1 \%$.

Basement at Site 793 is composed of hyaloclastite breccias and pillowed and massive lavas. It is an andesitic rock suite ranging from a $\mathrm{Mg}$-rich, $\mathrm{Cr}$-spinel-bearing, basaltic andesite with boninitic affinities to a more evolved, Mg-poor, siliceous andesite. Although many of the minerals are fresh, the glass is always altered to smectite. Again, low sulfur concentrations of $6-8 \mathrm{ppm}$ are present and $\delta^{34} \mathrm{~S}$ values are between $+3.0 \%$ oo and $+8.9 \%$ oo.

\section{DISCUSSION}

Sulfur is present in igneous rocks as sulfide and as sulfate. Studies of sulfide globules occurring in submarine basalts from the MidAtlantic Ridge $\left(37^{\circ} \mathrm{N}\right.$, Czamanske and Moore, 1977) show that the globules contain only about $1.5 \mathrm{wt} \%$ of the sulfur content in the rock; most of what remains is dissolved in the glass. Other investigations of submarine basalts (Kanehira et al., 1973; Mathez, 1976) and Hawaiian lavas (Desborough et al., 1968) have given similar results. Experimental data (Katsura and Nagashima, 1974; Carrol and Rutherford, 1985) and the natural occurrence of sulfate in basalts (Schneider, 1970; Sakai et al., 1982, 1984) suggest that the distribution of sulfur between sulfate and sulfide in igneous rocks depends on the oxygen fugacity. At an oxidation state close to QFM, the sulfide is dominant relative to sulfate in a hydrous silicate magma; however, at a higher oxygen fugacity (MNO, HM), anhydrite is a stable phase and the melt is sulfate dominant (Carrol and Rutherford, 1985).

Anhydrite microphenocrysts were found in the El Chichon pumices, but the magma was sulfide dominant (Rye et al., 1984). Dacites from Satsuma-Iwojima contain pyrrhotite and are saturated with respect to sulfur in spite of the low sulfur concentration (Ueda and Itaya, 1981), and similar observations have been made at other Japanese volcanic systems (Sakurajima and Okiura; Ueda and Sakai, 1984). $\mathrm{Fe}^{3+} /$ total $\mathrm{Fe}$ ratios in the Sumisu Rift basalts imply an oxygen fugacity just below the QFM at an eruption temperature of $1200^{\circ} \mathrm{C}$ (Hochstaedter et al., 1990), and the rocks are sulfide dominant. The mineral compositions in the rocks from Sites 790 and 791 suggest a higher water pressure and higher oxygen fugacity than that of MORB, like the Sumisu Rift basalts (Gill et al., this volume). The primary sulfur present in these igneous rocks studied is assumed, therefore, to have a sulfide/total sulfur ratio $\geq 0.5$ and occur as metal sulfides or be dissolved in the glass.

Alteration of the glass can cause enrichment or depletion of sulfur in the altered rock and thus the sulfur concentration may change and the sulfur isotopic composition also likely changes. The fresh mousse matrix and the very weakly altered samples from Site 790 are therefore the only samples that can be assumed to have retained their pristine magmatic $\delta^{34} \mathrm{~S}$ values. Stable isotope data of the mousse suggest that the lithic clasts have a different origin than the matrix (Gill et al., 1990). The $\delta \mathrm{D}$ value of the matrix glass is $-52.9 \%$, compared with the lithic clast value of $-70.7 \%$, and relatively close to the range in $\delta \mathrm{D}$ for the Sumisu Rift basalts, from $-30 \%$ o to -45 $\%$ (Hochstaedter et al., 1990). The sulfur isotope ratio range in the lithic clasts varies from $+11.0 \%$ oo to $+19.6 \%$, which ranges close to the seawater sulfate $\delta^{34} S$ value of $+20.2 \%$; the $\delta^{34} S$ of the matrix, on the other hand, has a typical magmatic value. As almost all of the sulfur in the lithic clasts is sulfate sulfur, it is indicated that the matrix $\delta^{34} \mathrm{~S}$ is not contaminated by the lithic clasts because sulfide sulfur is predominant in the matrix. Clearly, the lithic clasts have interacted more with seawater than the matrix. This is confirmed by the much higher carbon concentration in the lithic clasts and their $\delta^{13} \mathrm{C}$ value of $+0.2 \%$ o (Gill et al., 1990).

Sakai et al. (1982) modeled sulfur isotope fractionation, assuming degassing to be an equilibrium process, and found that the fractionation factor is dependent upon the relative proportions of sulfate and sulfide in the melt and $\mathrm{H}_{2} \mathrm{~S} / \mathrm{SO}_{2}$ in the vapor. The fractionation factor between gas and melt found at the Kilauean lavas was 1.0023 at a sulfate/sulfide ratio of $1 / 3$ between $\mathrm{SO}_{2}$ gas and sulfur in melt; but if the melt is sulfate deficient, the fractionation factor is 1.003 and will decrease with an increasing proportion of sulfate. This will result in 
a lowered $\delta^{34} \mathrm{~S}$ of the melt; if not, sulfate/total sulfur equals 0.6 or higher, then the $\delta^{34} \mathrm{~S}$ in the melt is increasingly higher. However, Taylor (1986) showed that the initial degassing from the Kilauean magma appeared to be dominated by reduction and decrease of $\delta^{34} \mathrm{~S}$ in the melt and the late-stage degassing appeared to be dominated by oxidation and an increase of $\delta^{34} \mathrm{~S}$ in the molten rock. Consequently, it appears that sulfate is preferentially lost from the magma during the degassing of $\mathrm{SO}_{2}$ and sulfide preferentially retained in the solidified rock.

The samples from Site 790 and the mousse matrix are highly vesicular (as are the Sumisu Rift lavas) and are likely degassed to some extent. Comparing the $\delta^{34} \mathrm{~S}$ values of the mousse and the Site 790 basalts (between $+0.2 \%$ and $+1.6 \%$ ) with Sumisu Rift basalt $\delta^{34} \mathrm{~S}$ values (between $-2.3 \%$ ond $+0.5 \%$, Hochstaedter et al., 1990 ), it is clear that these rocks cannot have the same sulfur source because the degassing process cannot produce such a large span in $\delta^{34} \mathrm{~S}$ values in rocks that are sulfide dominant or contain equal proportions of sulfide and sulfate as long as $\mathrm{SO}_{2}$ is the major sulfur species to be degassed. Any losses of sulfur through degassing should have produced a decrease in the $\delta^{34} \mathrm{~S}$ values. Sakai et al. (1984) showed that increasing water fugacity in magma could increase the proportion of sulfate compared with sulfide, as hydrogen fugacity would rise with increasing water fugacity. As the Sumisu Rift basalts show an inverse relationship between water content and $\mathrm{S}$ content or $\delta^{34} \mathrm{~S}$, but a positive relationship between $S$ content and $\delta^{34} \mathrm{~S}$, it is indicated that some of the isotope variation in the Sumisu Rift basalts could be explained by degassing. The more water-rich magmas could have had a higher proportion of sulfate sulfur, which escaped during the effervescence of $\mathrm{SO}_{2}$. However, the basalts from the backarc (Sites 790 and 791 and Sumisu Rift) with high water contents and thus high sulfate content during degassing would not have changed their $\delta^{34} \mathrm{~S}$ much, because the fractionation factors between gas and melt decrease with a higher proportion of sulfate. Hochstaedter et al. (1990) even suggested that the $\delta^{34} \mathrm{~S}$ of the Sumisu Rift basalts would resemble their primary isotopic composition.

The $\delta^{34} \mathrm{~S}$ values from the Izu Arc span a range from $+3 \%$ to $+6 \%$ (Ueda and Sakai, 1984), which may reflect a source between $+5 \%$ and $+7 \%$. Sulfur isotope composition in altered upper ocean crust has been shown to be little changed from igneous values (Alt et al., 1989a), whereas the recycling of marine sulfur occurs in the Mariana Arc (Woodhead et al., 1987). This suggests that the heavier $\delta^{34} S$ in the Izu Arc rocks is a result of the recycling of marine sulfur as seawater or sediments during subduction. The arc $\delta^{34} \mathrm{~S}$ values are higher than the values of the Sumisu Rift basalts and Site 790 basalts and mousse matrix (Fig. 2). It is interesting to note that the mousse matrix $\delta^{34} \mathrm{~S}$ values are intermediate between those of the arc and the Sumisu Rift basalts. Gill et al. (this volume) showed that the transition from arc to backarc magma types is much more rapid than previously had been imagined: the earliest basalts in the rift had some subduction-related characteristics, such as an $\mathrm{Nd}$ isotopic composition like the arc magmas, high water content, and negative $\mathrm{Ce}$ and $\mathrm{Nb}$ anomalies, but lacked high $\mathrm{Ba}$ concentrations and ${ }^{87} \mathrm{Sr} /{ }^{86} \mathrm{Sr}$ ratios to the right of the mantle array. Thus, the heavier $\delta^{34} \mathrm{~S}$ for the earliest basalts erupted in the rift could be subduction-related and the sulfur could be recycled marine sulfur to some extent.

At Hole 504B, Kusakabe et al. (1989) found that sulfur concentrations decrease as the degree of alteration increases, whereas the primary pyrrhotite is converted to pyrite and reaches final $\delta^{34} \mathrm{~S}$ values almost the same as in fresh basalt glasses. At forearc Sites 792 and 793, the sulfur concentration is low, the rocks are quite altered, and the $\delta^{34} \mathrm{~S}$ is similar to or higher than that of the present arc. However, this may be a coincidence because the formation of pyrite from pyrrhotite could cause changes in $\delta^{34} \mathrm{~S}$ as a result of the participation of heavy sulfate from seawater in the reaction (Shanks and Seyfried, 1987; Kusakabe et al., 1989).

The comparatively heavy sulfur isotope values (between $+9 \%$ and $+11 \%$ ) from the Site 791 basalts are more difficult to achieve. Sulfur isotope investigations on sulfides in basalts from Leg 37 yielded a wide span in $\delta^{34} \mathrm{~S}$, from $-33.4 \%$ oo to $-5.0 \%$ (Krouse et al., 1977), but $\delta^{34} \mathrm{~S}$ values as high as $+23.0 \%$ owere found in the Leg 34 cores (Field

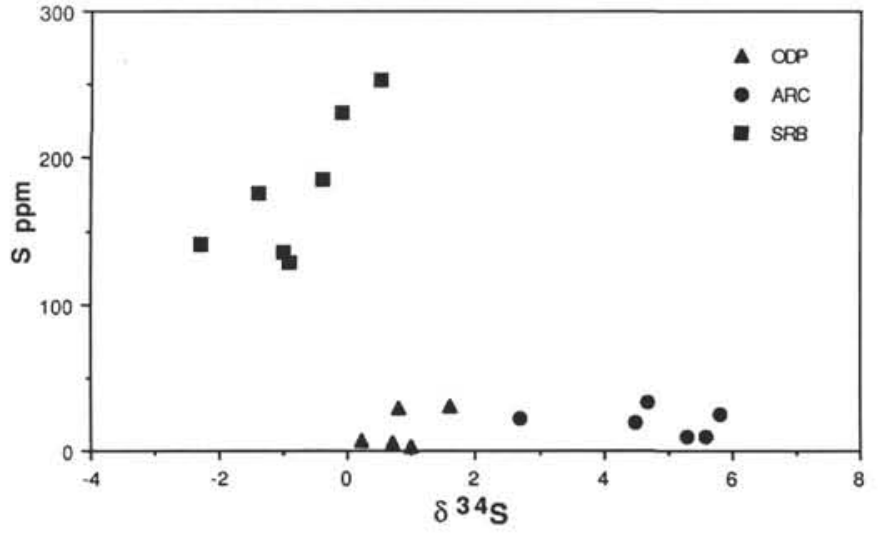

Figure 2. Sulfur concentration vs. sulfur isotope composition of fresh rocks from Leg 126 (ODP). Included in the figure are data from the Izu Arc (ARC; Ueda and Sakai, 1984) and Sumisu Rift basalts (SRB; Hochstaedter et al., 1990).

et al., 1976). Determination of the $\delta^{34} \mathrm{~S}$ values of rocks recovered from Hole 504B in the Costa Rica Rift (Alt et al., 1989a, 1989b; Hubberten, 1983; Kusakabe et al., 1989) found that at depth the $\delta^{34} \mathrm{~S}$ values are close to the meteoritic value of $0 \%$ o, whereas $\delta^{34} \mathrm{~S}$ in the transition zone at intermediate depth ranges from $+0.2 \%$ to $+5.6 \%$. However, an even larger range in $\delta^{34} \mathrm{~S}$ values $(-4.1 \%$ o to $+8.2 \%$ ) was found in ion microprobe analyses (Alt and Chaussidon, 1989). These higher $\delta^{34} \mathrm{~S}$ values from the hydrothermally altered rocks are comparable to $\delta^{34} \mathrm{~S}$ values from hydrothermal fluids and sulfide deposits from the seafloor of up to about $+7 \%$ (Arnold and Sheppard, 1981; Styrt et al., 1981; Skirrow and Coleman, 1982; Shanks and Seyfried, 1987) and to basalt-seawater experiments yielding pyrite $\delta^{34} \mathrm{~S}$ values of about $+10 \%$ (Shanks et al., 1981). Thus, the increase in $\delta^{34} \mathrm{~S}$ relative to pristine ocean floor basalts is interpreted to arise from the incorporation of sulfide derived from the seawater sulfate reduction. The heavy sulfur isotope ratios in the Site 791 basalts are thus best explained by the addition of sulfide with a seawater sulfate origin. Bacterial sulfate reduction produces a much larger fractionation and typically negative $\delta^{34} \mathrm{~S}$ values, so it is not likely that this process produced any of the high $\delta^{34} \mathrm{~S}$ values found. The inorganic sulfate reduction requires temperatures in excess of $250^{\circ} \mathrm{C}$, but the alteration mineralogy does not give any indication of such a high temperature in the lavas at Site 791. In the hydrothermally altered material beneath the mousse, chlorite is found, which indicates a higher temperature than in the lavas above. Clearly, the interpretation of the addition of sulfur through inorganic sulfate reduction is only tentative. The similar $\delta^{34} \mathrm{~S}$ values of sulfate sulfur from these rocks cannot be explained by interaction with any hydrothermal fluids, because the fractionation between sulfide and sulfate is large if sulfate reduction occurred. The sulfate must arise from a process that yields little or no fractionation at all, such as oxidation. However, such oxidation cannot involve the formation of thiosulfate ions (Field et al., 1976), because that would cause a large isotope fractionation.

\section{CONCLUSIONS}

The sulfur isotope composition of the igneous rocks verifies that there is a difference between the earliest and later magmas in the backarc environment. The earliest magmas from the initiation of the rift have $\delta^{34} \mathrm{~S}$ values more like those of the arc than those of the later Sumisu Rift basalts.

Alteration of the rocks caused by interaction with seawater has changed the sulfur isotope composition of most of the rocks toward heavier $\delta^{34} \mathrm{~S}$ values.

\section{ACKNOWLEDGMENTS}

This study was financed by the Swedish Natural Science Research Council. 


\section{REFERENCES}

Alt, J. C., Anderson, T. F., and Bonnell, L., 1989a. Geochemistry of sulfur in a $1.3 \mathrm{~km}$ section of hydrothermally altered oceanic crust, DSDP Hole 504B. Geochim. Cosmochim. Acta, 53:1011-1023.

Alt, J. C., Anderson, T. F., Bonnell, L., and Muehlenbachs, K., 1989b. Mineralogy, chemistry, and stable isotopic compositions of hydrothermally altered sheeted dikes: ODP Hole 504B, Leg 111. In Becker, K., Sakai, H., et al., Proc. ODP, Sci. Results, 111: College Station, TX (Ocean Drilling Program), 27-40.

Alt, J. C., and Chaussidon, M., 1990. Ion microprobe analyses of the sulfur isotopic composition of sulfides in hydrothermally altered rocks, DSDP/ODP Hole 504B. In Becker, K., Sakai, H., et al., Proc. ODP, Sci. Results, 111: College Station, TX (Ocean Drilling Program), 41-45.

Arnold, M., and Sheppard, S.M.F., 1981. East Pacific Rise $21^{\circ}$ N: isotopic composition and origin of the hydrothermal sulfur. Earth Planet. Sci. Lett. $56: 148-156$

Carrol, M. R., and Rutherford, M. J., 1985. Sulfide and sulfate saturation in hydrous silicate melts. J. Geophys. Res, 90 (suppl.):c601-c612.

Chaussidon, M. F., Albarede, F., and Sheppard, S.M.F., 1987. Sulphur isotope heterogeneity in the mantle from ion microprobe measurements of sulphide inclusions in diamonds. Nature, 330:242-244.

Czamanske, G. K., and Moore, J. G., 1977. Composition and phase chemistry of sulfide globules in basalt from the Mid-Atlantic Ridge rift valley near $37^{\circ} \mathrm{N}$ lat. Geol. Soc. Am. Bull., 88:587-599.

Desborough, G. A., Anderson, A. T., and Wright, T. L., 1968. Mineralogy of sulfides from certain Hawaiian basalts. Econ. Geol., 63:636-644.

Field, C. W., Demond, J. R., Heath, G. R., Corliss, J. B., and Dasch, E. J., 1976. Sulfur isotope reconnaissance of epigenetic pyrite in ocean floor basalts, Leg 34 and elsewhere. In Yeats, R. S., Hart, S. R., et al., Init. Repts. DSDP, 34: Washington (U.S. Govt. Printing Office), 381-384.

Garcia, M. O., Liu, N.W.K., and Muenow, D. W., 1979. Volatiles in submarine volcanic rocks from the Mariana Island arc and trough. Geochim. Cosmochim. Acta, 43:305-312

Gill, J., Torssander, P., Lapierre, H., Taylor, R., Kaiho, K., Koyama, M., Aitchison, J., Cisowski, S., Dadey, K., Fujioka, K., Klaus, A., Lovell, M. Marsaglia, K., Pezard, P., Taylor, B., and Tazaki, K., 1990. Explosive deep water basalt in the Sumisu backarc rift. Science, 248:1214-1217.

Grinenko, V. A., Dmitriev, L. V., Migdisov, A. A., and Sharaskin, A. Y., 1975. Sulfur contents and isotope composition for igneous and metamorphic rocks from mid-ocean ridges. Geochem. Int., 12:132-137.

Harmon, R. S., Hoefs, J., and Wedepohl, K. H., 1987. Stable isotope (O, H, S) relationships in Tertiary basalts and their mantle xenoliths from the northern Hessian Depression, W. Germany. Contrib. Mineral. Petrol., 95:350-369.

Hochstaedter, A. G., Gill, J. B., Kusakabe, M., Newman, S., Pringle, M., Taylor, B., and Fryer, P., 1990. Volcanism in the Sumisu Rift. I. Major element, volatile and stable isotope geochemistry. Earth Planet. Sci. Lett. 100:179-194.

Hubberten, H.-W., 1983. Sulfur content and sulfur isotopes of basalts from the Costa Rica Rift (Hole 504B, Deep Sea Drilling Project Legs 69 and 70). In Cann, J. R., Langseth, M. G., Honnorez, J., Von Herzen, R. P., White, S. M., et al., Init. Repts. DSDP, 69: Washington (U.S. Govt. Printing Office), 629-635.

Kanehira, K., Yui, S., Sakai, H., and Sasaki, A., 1973. Sulphide globules and sulphur isotope ratios in the abyssal tholeiite from the Mid-Atlantic Ridge near $30^{\circ} \mathrm{C}$ latitude. Geochem. J., 7:89-96.

Katsura, T., and Nagashima, S., 1974. Solubility of sulfur in some magmas at 1 atmosphere. Geochim. Cosmochim. Acta, 42:517-531.

Kiba, T., Tagaki, T., Yoshimura, Y., and Kishi, I., 1955. Tin (II)-strong phosphoric acid. A new reagent for the determination of sulfate by reduction to hydrogen sulfide. Bull. Chem. Soc. Jpn., 28:641-644.

Krouse, H. R., Brown, H. M., and Farquharsson, R. B., 1977. Sulfur isotope compositions of sulfides and sulfates, DSDP Leg 37. Can. J. Earth Sci., 14:787-793.

Kusakabe, M., Mayeda, S., and Nakamura, E., 1990. S, O and Sr isotope systematics of active vent materials from the Mariana backarc basin spreading axis at $18^{\circ} \mathrm{N}$. Earth Planet. Sci. Lett., 100:275-282.

Kusakabe, M., Shibata, T., Yamamoto, M., Mayeda, S., Kagami, H., Honma, H., Masuda, H., and Sakai, H., 1989. Petrology and isotope characteristics $(\mathrm{H}, \mathrm{O}, \mathrm{S}, \mathrm{Sr}$, and $\mathrm{Nd})$ of basalts from Ocean Drilling Program Hole 504B,
Leg 111, Costa Rica Rift. In Becker, K., Sakai, H., et al., Proc. ODP, Sci. Results, 111: College Station, TX (Ocean Drilling Program), 47-60.

Mathez, E. A., 1976. Sulfur solubility and magmatic sulfides in submarine basalt glass. J. Geophys. Res., 81:4269-4275.

Moore, J. G., and Fabbi, B. P., 1971. An estimate of the juvenile sulfur content of basalt. Contrib. Mineral. Petrol., 33:118-127.

Puchelt, H., and Hubberten, H. W., 1980. Preliminary results of sulfur isotope investigations on Deep Sea Drilling Project cores from Legs 52 and 53. In Donnelly, T., Francheteau, T., Bryan, W., Robinson, P., Flower, M., Salisbury, M., et al., Init. Repts. DSDP, 51, 52, 53, Pt. 2: Washington (U.S. Govt. Printing Office), 1145-1148

Robinson, B. W., and Kusakabe, M., 1975. Quantitative preparation of sulfur dioxide, for ${ }^{34} \mathrm{~S} /{ }^{32} \mathrm{~S}$ analyses, from sulfides by combustion with cuprous oxide. Anal. Chem., 47:1179-1181.

Rye, R. O., Luhr, J. F., and Wasserman, M. D., 1984. Sulfur and oxygen isotope systematics of the 1982 eruptions of El Chicón volcano, Chiapas, Mexico. J.Volcanol. Geotherm. Res., 23:109-123.

Sakai, H., Casadevall, T. J., and Moore, J. G., 1982. Chemistry and isotope ratios of sulfur in basalts and volcanic gases at Kilauea volcano, Hawaii. Geochim. Cosmochim. Acta, 46:729-738.

Sakai, H., Des Marais, D. J., Ueda, A., and Moore, J. G., 1984. Concentrations and isotope ratios of carbon, nitrogen and sulfur in ocean-floor basalts. Geochim. Cosmochim. Acta, 48:2433-2441.

Schneider, A., 1970. The sulfur isotope composition of basaltic rocks. Contrib. Mineral. Petrol., 25:95-124.

Shanks, W. C., III, Bischoff, J. L., and Rosenbauer, R. J., 1981. Seawater sulfate reduction and sulfur isotope fractionation in basaltic systems: interaction of seawater with fayalite and magnetite at $200-350^{\circ} \mathrm{C}$. Geochim. Cosmochim. Acta, 45:1977-1995.

Shanks, W. C., III, and Seyfried, W. E., Jr., 1987. Stable isotope studies of vent fluids and chimney minerals, southern Juan de Fuca Ridge: sodium metasomatism and seawater sulfate reduction. J. Geophys. Res., 92:11,38711,399 .

Shima, M., Gross, W. H., and Thode, H. G., 1963. Sulfur isotope abundances in basic sills, differentiated granites and meteorites. J. Geophys. Res., 68:2835-2847.

Skirrow, R., and Coleman, M. L., 1982. Origin of sulphur and geothermometry of hydrothermal sulphides from the Galapagos Rift, $86^{\circ} \mathrm{W}$. Nature, 299:142-144.

Smitheringale, W. G., and Jensen, M. L., 1963. Sulfur isotopic composition of the Triassic igneous rocks of eastern United States. Geochim. Cosmochim. Acta, 27:1183-1207.

Styrt, M. M., Brackmann, A. J., Holland, H. D., Clark, B. C., Pisutha-Arnond, V., Eldridge, C. S., and Ohmoto, H., 1981. The mineralogy and isotopic composition of sulfur in hydrothermal sulfide/sulfate deposits on the East Pacific Rise, $21^{\circ} \mathrm{N}$ latitude. Earth Planet. Sci. Lett., 53:382-390.

Taylor, B. E., 1986. Magmatic volatiles: isotopic variation of C, H and S. In Valley, J. W., Taylor, H. P., O'Neil, J. R. (Eds.), Stable Isotopes in Geological Processes. Mineral. Soc. Am., Rev. Mineral., 16:185-226.

Torssander, P., 1989. Sulfur isotope ratios of Icelandic rocks. Contrib. Mineral. Petrol, 102:18-23.

Ueda, A., and Itaya, T., 1981. Microphenocrystic pyrrhotite from dacite rocks of Satsuma-Iwojima, southwest Kyushu, Japan and the solubility of sulfur in dacite magma. Contrib. Mineral. Petrol., 78:21-26.

Ueda, A., and Sakai, H., 1983. Simultaneous determinations of the concentration and isotope ratio of sulfate- and sulfide-sulfur and carbonate carbon in geological samples. Geochem. J., 17:185-196.

1984. Sulfur isotope study of Quaternary volcanic rocks from the Japanese Islands Arc. Geochim. Cosmochim. Acta, 48:1837-1848.

Woodhead, J. D., Harmon, R. S., and Fraser, D. G., 1987. O, S, Sr and Pb isotope variations in volcanic rocks from the northern Mariana Islands: implications for crustal recycling in intra-oceanic arcs. Earth Planet. Sci. Lett., 83:39-52.

Date of initial receipt: 8 February 1991

Date of acceptance: 19 August 1991

Ms 126B-148 